\title{
Téoros
}

Revue de recherche en tourisme

\section{Tourism Destination Development and Problems of Management: Case Lake Memphremagog Region}

\section{Jan O. J. Lundgren}

Volume 7, numéro 2, juillet 1988

Villégiature et tourisme

URI : https://id.erudit.org/iderudit/1080409ar

DOI : https://doi.org/10.7202/1080409ar

Aller au sommaire du numéro

Éditeur(s)

Université du Québec à Montréal

ISSN

0712-8657 (imprimé)

1923-2705 (numérique)

Découvrir la revue

Citer cet article

Lundgren, J. O. J. (1988). Tourism Destination Development and Problems of Management: Case Lake Memphremagog Region. Téoros, 7(2), 11-16.

https://doi.org/10.7202/1080409ar d'utilisation que vous pouvez consulter en ligne. 
Dans cet article, l'auteur discute d'abord de quelques concepts reliés au processus de développement touristique. Ensuite, il observe comment ce processus s'est déroulé dans la région du lac Memphrémagog. Enfin, l'auteur émet quelques propositions pour éviter "la destruction du tourisme par le tourisme".

The purpose of this presentation is threefold: first, it elaborates some conceptual aspects pertaining to the touristic development process, aspects that on the whole are familiar to the academic researchers, that over the past decades have followed and studied the modern tourism phenomenon; as a second objective, the paper wants to focus upon a region with a long history of tourism, but where in more recent times the development process has accelerated. It is fair to say that in the past few years our study area the Lake Memphremagog region - can be described as one of the "hottest" prospects for tourist industry entrepreneurship whithin an easy reach of the greater metropolitan Montreal area and the more heavily urbanized St. Lawrence River corridor. The spatial patterns of the recreational resources potential in the study region will be discussed in order to place the present development tendencies in their proper context, by which some important "breaks" also will be demonstrated in the region's recreationaltouristic evolution, breaks that are changing the directions of the touristic impacting. The third and final purpose is to highlight some of the deficiencies in the present format of tourist resource exploitation and at the same time forwarding suggestions as to what in principle would have to be done in order to avoid the otherwise ominous ultimate dictum of excessive tourist destination development: to paraphrase an originally German saying: destruction of tourism through tourism.

+ Jan O.J. Lundgren est professeur au Departement de géographie de I'Université McGill.

\section{Some concepts elaborated}

The tourism phenomenon involves basically three major strongly interdepedent elements that together constitute a distinct spatial transect construct if seen from the prospective traveller's perspective (fig. 1) a distinct travel-generating area usually centered on major urban-metropolitan regions, from which over the year the travel movement flow is emitted over a recreationaltouristic destinarion space, where discreet destinations can be identified. The spatial dimensions of the component construct is a function of many factors: the generation of flow level depends on income, leisure time availability, mode of transports, information and promotion of competing destination, the geographic landscape attributes in the destination space to mention some. The spatial extent of the combined set of components varies, reflecting the wishes of the market and the spatial organization of the supply including the destinations. It is important to recognize that the three components described above can either be quite strongly coordinated, which is the case for longdistance tour packages, or they can make up a more loosely interrelated "spatial system". Marketing studies have focussed upon identifying the elements of various travel segments; geographic research has tended to be more concerned with the end part of the system - the destination, into which the travel movements flow and where the transposed demands of the travelling public are being felt. It is here - in the destination environment - that the tourist-derived consumption process occurs, because here can be found the principal set of attractions that trigger the travel movement in the first place. It is in the destination milieu that the tourist consumes the "tourist product"' through the assistance of a wide range of facilitating services such as accomodation, food and restaurants, local transport, guide and skill services to mention some.

The concept of the Tourist Product (TP) is central to our analysis. Traditionally the tourist product has been defined as a concept embracing all types of inputs essential to the tourist as he/she moves from the origin area along the transport transect to the destination(-s) and back. Thus travel agency services in the generating area as well as canoe rentals in the destination are included. For our purposes this is too broad and unpractical a definition, especially as our concern is with the destination environment, both physical and manmade, simply because this geo- graphic entity represents the ultimate focal point of the demands generated by the traveller. Here we find the aggregate locational juxtaposition of the individual travellers" wishes and it is in the same location that the traveller "consumes" the product destination. Thus, the yardstick against which the tourist consumption must be measured is the ultimate destination area toward which his leisure time allocation and associated consumer attributes are directed.

Given the above definition of the TP - a geographically identifiable and often distinctly delimited entity - a second conceptual aspect must be recognized: TP:s show marked differences in their composition their "make-up" which in turn have important consequences as far as their development potential goes, especially their ability to accomodate visitor inflow levels. Figure 2 schematizes three types of TP destinations: at one extreme we recognize a TP with a onesided, highly skewed composition - type " A" is typical for outdoor recreation destinations in the periphery of urban recreational hinterlands, with a strong resource-oriented profile, nature and wilderness being by far the main attraction elements toward which the touristic consumption is directed, and featuring only simple and basic visitor support services, In contrast, for " $\mathrm{C}$ ", a multitude of manmade facilities and services are in themselves the set of attractions, sometimes against impressive geographic landscapes backdrops that also could act as destination area resources, but as often are secondary as attractions in the destination's make-up. International gambling resort areas, Las Vegas, Reno, Atlantic City et al., would fall in to this type of TP composition. The third, intermediate TP type may have a balance of components, some resourcebased, some service-derived and a third category which often is a mix of culturalhistorical and socio-cultural elements combined with the essential personal services as in type " $\mathrm{B}$ ". Thus, this TP type contains a variety of attraction features, some of which are areally extensive landscape facets sprinkled with cultural elements which makes for a territorially extensive cultural-geographic landscape; on the other hand, other cultural features may be quite nodal and pointlike in character - historic sites and buildings located both in urban and rural environments. The service component may have its own touristic appeal as well as serving as a support element to visitors "consuming" the other two TP components. 
It is important to recognize the differences in TP make-up because they have consequences for the ability of a destination to absorb visitor inflows. Thus, we must introduce the final concept, always at work in any TP destination - the evolution/development process, a phenomenon which is an inevitable but crucial factor. Consequently, we can conclude that the development of a TP destination in terms of increasing visitor inflows must be seen against the global dimensions of the TP and the ability of its various components to handle the imported demands. Clearly there are limits and these limits, or carrying capacities, for the respective components differ. On the whole, and very simplified, the physical landscape component responds poorly to increased visitor use: the component is very "inelastic" in its response to demand increases, a fact that is easy to see by for instance observing how a beach shoreline gradually fills up with visitors to a certain acceptable density level, beyond which for comfort or visitor pleasure the beach administrators are reluctant to go. Similarly, the development of cottage occupance at a given subdivision density eventually fills up the whole accessible shoreline; only under certain circumstances can the shoreline be extended, being made more "elastic", by for instance manmade indentations permitting a larger number of cottages than its natural state would permit; in contrast, the service component of the TP make-up is usually the most elastic of the TP make-up in face of increasing visitor pressures: if a restaurant or hotel runs out of capacity more consistently, the managers will most likely expand in one way or another, or establish new capacity on new locations within the destination area; similarly, if a ski hill starts to get a reputation of having slow-moving lift lines the operator will most likely introduce either faster-moving lifts, or replacing the twochair system with a four-seat chair system. Cultural-historical elements in the TP are perhaps the most difficult to assess in terms of their carrying capacity levels. A good quality visitor experience of such features requires that visitor volumes do not impair the visitor enjoyment of the various elements that are critical to the "setting" or to existing ambiance. Also, too much visitor disturbance may dilute the quality of the visitor impression. Hence, for certain national parks there exists a policy of "no air services" nor may overflights be permitted because it disturbs the atmosphere and the serenity of the environment. Similarly, and closer to home, there are lake associations in the Laurentians that prohibit the use of motordriven boats on lakes they control - again in order to preserve a pristine quality of silence or peacefulness. The question arises of course at which level one should set the permissible disturbance and the same goes on the whole for a tourist destination: what is the appropriate visitor inflow, a question that becomes essential to grapple with when one considers development strategies for tourist destinations. In open economic systems, which permits access to most tourist desti-

FIGURE 1

The tourist travel phenomenon

(Components and distance range)

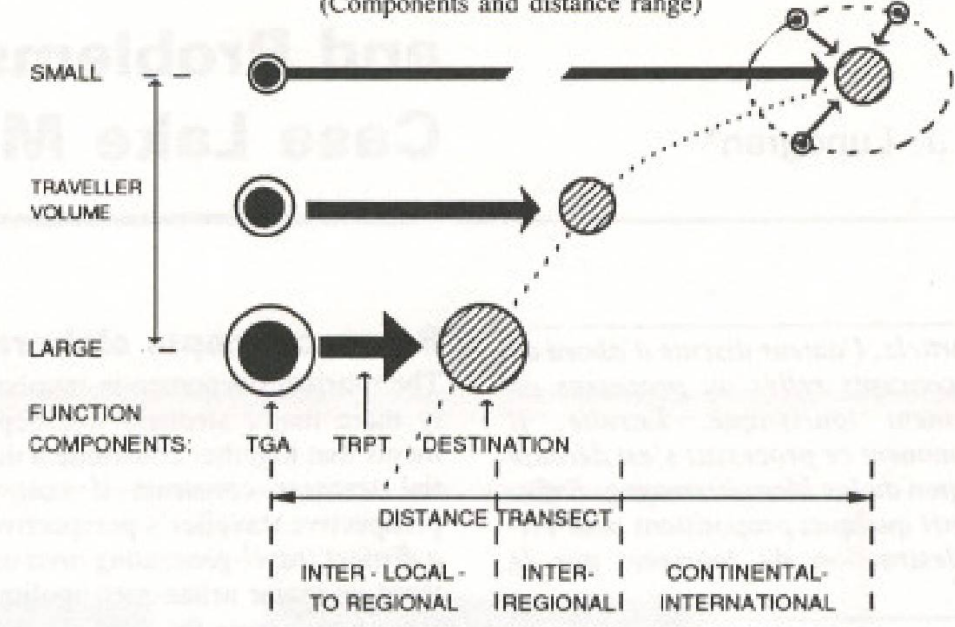

JL. 88

FIGURE 2

Tourist Product $(=$ TP) Composition

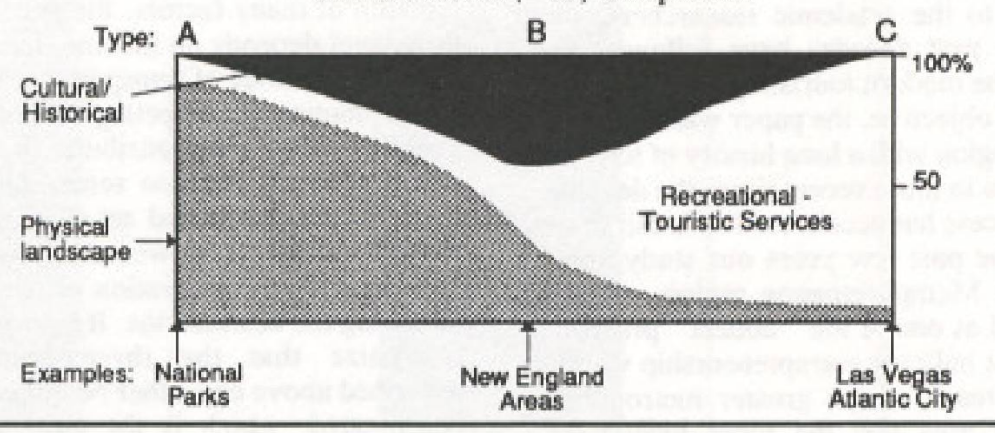

nations it is hard to enforce any form of visitor limit. However, it is frequently done indirectly by "permits", by for instance traffic control, parking area policies, and day passes to visitors. For instance, in Vermont and elsewhere in New England ski hill operators have a policy of limiting the number of tickets sold per day in order to ensure "customer satisfaction" and avoid overcrowding. The last and perhaps the most critical concept to consider for destination area developments concern their cycle of evolution, a concept which in broad terms can be compared with the notion of product's development/sales cycle. The application of this growth cycle concept to tourist destinations is not unique per se, but becomes slightly more complex because of the less tangible attributes associated with a TP compared to, say, a new camera model. Again, the geographic elements, particularly the environmental parts make for a less finite product. both in terms of promotion and marketing and consumption.

The application of the TP cycle of evolution concept was first done by R. Butler - a geographer at the University of Western Ontario; it was very much based upon empirical observations of tourist resort area developments in different parts of the world, but especially in locations where over time strong market demand had manifested itself and produced what can be described, in the more final stages, various types of high density tourist destination milieus. Obviously, the concept as such was not new - it has figured prominently in economics and business-related research, as well as in biology and other sciences. However, Butler combined, and brought together in the analysis, the quite disparate elements that make up the growth cycle and related them to the consumption and the TP product being consumed. He stressed the rate of consumption of a destination and the consequences inherent in the final stage of the product consumption, i.e. the state of the TP at the end of the "cycle" of evolution (fig. 3). He stresses both in principle and by hard (and harsh) realities that all tourist destinations (Tourist Products) undergo a product cycle of evolution characterized by a slow early stage with small visitor inflows, followed by an acceleration stage (not different from Rostow's take-off and drive-to-maturity stages in the development process), where tourist volume grows fast and more of the available touristic resources in the TP are activated, which in turn leads to the final stage of consolidation-stagnation, when critical levels of visitor pressures upon the destination resources slow down the rate of growth to either close to zero (or even to a negative). Butler's model has a good fit - not only on specific 

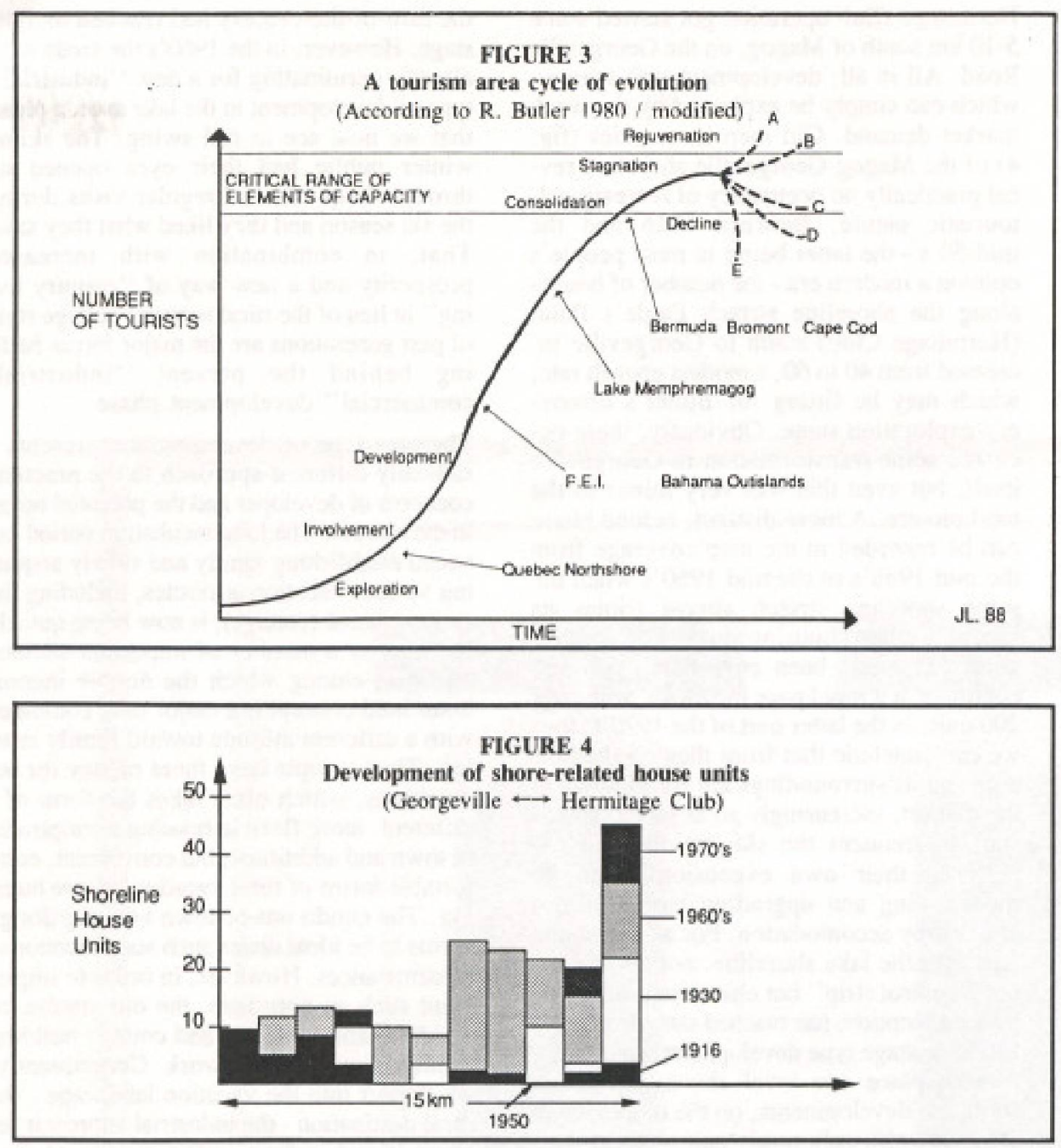

locations but also on larger "national" destinations that have been part of the international tourist market for a longer time period. Two important considerations underlie Bu= tler's application: first, the rate of development observed is set against the notion of finite resources available for any tourist destination, existing ones as well as those yet to be discovered. Thus, the pressures upon the various attraction elements of a destination can (and should) be measured both prior to a development undertaking and on a regular basis during the subsequent evolution cycle. By doing this one can in principle establish the rate of "transformation" of critical attraction elements from their original state. One can, as a minimum, arrive at indicators of "carrying capacity" levels both aggregately and for specific TP elements. Thus, regardless of whether we deal with completely spontaneous developed destinations or with a more controlled situation, assessments of the destination area's qualitative level as an attraction can be made and corrective measures can be implemented should the findings so justify. Second, there are limits to growh for tourist destinations! It may be hard to agree upon at what levels the limits for a destination start to become critical; they are invariably reached and must be taken seriously by individual commercial operators in a destination and by public sec- tive geographic setting by which one can appreciate its competitiveness in the market and its attraction make-up better; the second level of analysis involves an accounting of the specifics in the spontaneous development process that the area has experienced, particularly demonstrating the relationship of the development realities to the resource makeup. A third but separate step in the analysis involves a discussion of the problems that the more recent development phase has created in a broader, regional context, but also at a more localized level. The conclusions are really in the form of a set of suggestions by which a more systematic and controlled development can be seen as an alternative to the present, more free-for-all approach, which, in the long run will feature many of the negative attributes as outlined in Butler's model.

The geographic shape of any destination carries implications in terms of subsequent touristic-recreational resource exploitation and overall development. In contrast to the Montreal Laurentians, where principal landscape features conducive for outdoor recreation are partically omnipresent - according to official land inventory surveys - the Eastern Townships region in general, and the Lake Memphremagog area in particular offer outdoor recreational opportunities in a more concentrated fashion. This geographic reality produces strong destination foci for the Montreal-based recreational-touristic travel flows. As a result we have seen concentrations of tourist flows to select destinations, especially when major obstacles (for instance a poor road network) have been removed. Thus, Bromont, Sutton, Orford and Owl's Head have developed as major tourist centers in the 1960's, very much aided by the opening of the autoroute into the region, which reduced travel time from Montreal by half. Topography and winter climate clearly play a role as creators of "central places" for the potential visitors to the region, producing multiplier effects in terms of demand for services located in the surroundings of these locations.

However, what makes the area's potential of top caliber in comparative terms is the existence of numerous, substantial lakes, that so far have remained clean, although the situation has been precarious from time to time. Starting at the western edge of the region we have Brome Lake, and hour's drive from Montreal and offering good public access to the shoreline along its eastern side and in addition providing an excellent municipal beach. As one travels east the Outdoor Recreational Land Potential score literally improves with topograhy, but with the "lake factor" " playing a strong supportive role. Within 1/2 hour's drive from Magog, at the northern tip of Lake Memphremagog, the landscape score is dominated by classes 1-3, which provide "excellent opportunity to popular forms of outdoor recreation" to paraphrase the definitions of these three classes. In fact, access to good recrational land is very high and is found in considerable abundance within a $30 \times 50 \mathrm{~km}$ territo- 
ry with the big lake positioned in the center of the territory. No wonder than, that this part of Quebec with its surroundings is considered as highly attractive locations for highpriced individually owned country homes as well as for developers interested in exploiting the land resources for substantial resort like condominium schemes and other types of "tourist industry" facilities ski lifts, golf courses, commercial marinas, etc. Alternative development areas elsewhere are usually either so fully developed that it is difficult to impose any new schemes which is the case in the Montreal Laurentians - or they may be too inaccessible to be viable "development" prospects as in the case (of) further east - toward Lake Megantic -, or they may be located across the border in the US, which may complicate matters. Thus, the Lake Memphremagog region possesses a resource base that is outstanding and the region can be reached in approximately 1.5 hour's drive from Montreal.

\section{The development process at work}

Given the relative resource scarcity, in recreational-touristic terms, in the landscape around the expanding metropolitan area, combined with the limitations imposed by the lack of efficient transport it is not surprising that initial tourist-based development only slowly spread across the St. Lawrence plain toward the Eastern Townships' foothills, as well as north, toward the Laurentians. As access improved, so did the prospects for a touristic development; thus, for a long time the touristic penetration was, if not haphazard, at least spotty, often occurring in adjunct with rural settlements and along local transport lines, they be waterborne or overland. Substantial country homes and properties were acquired by Montrealers, sometimes from local farmers that were happy to part with some land for cash, sometimes inherited from the rural branch of the family, where younger generations had "made it "in town. This process of penetration is perhaps most typical in the Eastern Townships and is not as distinct in other resort areas of the past - Murray Bay (Malbaie), Metis, Cacouna where there was less of hereditary linkage with agricultural sector. The early tourist development in the Lake Memphremagog area seems to have been a fairly intimate process between townspeople and locals.

Access was poor until 1902, when the Waterloo-Magog rail line was extended, resulting in direct services from Montreal. Prior to this date, access had made tourist developments veer south before hitting the lake, affecting such places as Knowlton and the Missisquoi River Valley, where an early resort development had been established at Potton Springs, south of S. Bolton. There were some early developments at the middle of the Lake, where the traditional ferry crossings had provided links and lines of access - Austin Bay, Gibraltar Point, Georgeville and the lakeside of Owl's Head.

Not until the early 1920's however did more substantial developments occur when the
Hermitage Club operation got started some $5-10 \mathrm{~km}$ south of Magog, on the Georgeville Road. All in all, development was scarce which can simply be explained by the weak market demand. Old map inventories (fig. 4) of the Magog-Georgeville shoreline reveal practically no occupancy of recreationaltouristic nature. Between 1916 and the mid-50's - the latter being in most people's opinion a modern era - the number of houses along the shoreline stretch Eagle's Point (Hermitage Club) south to Georgeville increased from 40 to 60 , a modest growth rate, which may be fitting for Butler's discovery/exploration stage. Obviously, there occurred some transformation in Georgeville itself, but even this was very minor in the total picture. A more distinct, second phase can be recorded in the map coverage from the mid 1950's to the mid 1960's when the same shoreline stretch almost triples its vacation-related housing stock. The acceleration phase has been embarked upon and continues at a rapid pace forthwith, with over 200 units in the latter part of the 1970's; thus we can conclude that from then on the lake area and its surroundings are well known to the market, increasingly so as large crowds start to frequent the ski stations that experience their own expansion boom by modernizing and upgrading base facilities and nearby accomodation. For all intent and purposes the lake shoreline, not only along our " "control strip" ' but elsewhere, with only minor exception, has reached saturation. Any further cottage type development would have to take place one level above the earlier shoreline developments, on the other side of the road, with only rarely guaranteed access or right-of-way through already established shoreline properties. Thus, we can already at this stage see the "pressure of access" to the lake mount, initiating the strong seasonal demand on the very few public access points around the lake, at Magog, Georgeville, Knowlton Landing, and Vale Perkins. The only missing demand element materialized later when large day excursion crowds descended upon these entry points to the lake for pleasure boating - which is the current situation - producing "make-shift" marina environments on a big scale.

A similar shoreline occupancy development occurred west of Magog and west of Cherry River estuary: here there was little, if any development for a long time; even in the late $1940^{\prime}$ 's the shoreline was practically empty. Since, the whole shoreline has become literally urbanized, so much that it forms part of the urban district of Magog; likewise, from Magog south toward the Hermitage Club the shoreline urbanization has proceeded, part= ly as a function of demand from outside the region, but also locally generated, as local residents and Magog townspeople upgraded their residential housing into finer, more scenic locations.

The 1970 's seem to represent a plateau in a development cycle, typified by the final closure of broad, informal lake-shoreline access by complete occupancy literally around the lake; a development that was started at the turn-of-the-century had reached its final stage. However, in the 1960 's the seeds were already germinating for a new "industrial" type of development in the lake area, a phase that we now see in full swing. The skiing winter public had their eyes opened up through frequent, and regular visits during the ski season and they liked what they saw. That, in combination with increased prosperity and a new way of "country living" in lieu of the rural summer cottage style of past generations are the major forces fuelling behind the present "industrialcommercial" development phase.

The new type of development represents a radically different approach to the practical concerns of developer and the potential buyer in the market. The long incubation period between establishing family and slowly acquiring various vacation attributes, including the country home (cottage), is now being quickly reduced by a number of important societal changes, among which the double income household concept is a major one, combined with a different attitude toward family rearing. Thus, people have more money for acquisitions, which often takes the form of a different, more flexible housing arrangement in town and additional, but convenient, comfortable forms of rural vacation/leisure housing. The condo out-of-town housing design seems to be ideal under such socio-economic circumstances. However, in order to implement such an approach, the old simple individual land purchase and cottage building arrangement does not work. Consequently, we import into the vacation landscape - the rural destination - the industrial approach because it makes for an efficient use of construction technology, admittedly not necessarily suited or fitting in the new non-urban local context. Thus, the "industrial developer" for the vacation market has emerged. This new type has his own distinct attributes, that make him different from the "developer" of old times. Some of these can be described as below. The listing is incomplete, but gives us some idea of the radical= ly new situation that the tourist destination (potential) is facing:

1- Large scale capitalization compared with the past: in contrast to the old approach where the buyer purchased land and "cottage" one at a time for a price range between $\$ 20.000-100.000$ for personal use; the new approach involves the construction of a number of household units within a development compound - the condo complex usually conforming to urban living requirements. Consequently, more land, more units, higher levels of capitalization are principal requirements.

2- Extra-regional development interesis: as the scale of projects increases, and with that the capitalization requirements, it becomes less likely that the developer is local to the region. Project design and financing become important factors, that rarely can be handled locally. Thus emerges the controlling developer or de- 
velopment consortium which formulates the development package in which local contractors may be involved. Even so, project scale and overall project sophistication may be on such a level that only extra-regional contracting companies can handle the physical construction phase of the scheme.

3- Conceptualization of the development design: appearance, as well as its technical standards, is extra-regional in origin; therefore there is often a "lack-offit" " with existing local characteristics. For example, one might find a popular style - say Cape Code cottage type - introduced in an area at the expense of whatever distinct local designs are available. In addition, the urban technical solution may even further shield the future owner from the local environment. Example: indoor climate control and hermetically sealed windows.

4- High density project design essential to the industrial approach: considerable economization can be achieved by a concentrated type of development. Thus, saving on land, project infrastructure and the like makes it often possible to site the project in confined spaces, often between traditional, low density tourist occupancy. This means that the impacting generated by the new development must be absorbed by the surrounding area without any compensation to its occupants. Any concentration of occupance above the average for a wider area produces overall higher pressure upon environmental resources, especially upon those that have recreational value; thus, by and large, the satisfaction level for already established occupants will be reduced. The concept of "buffer zones" could solve the problem, but is not used, simply because in most cases insufficient land is available for the developer to implement such devices. Consequently practically all high density, new development schemes are in direct contact with units belonging to the earlier low density occupancy phase.

5- New high density developments emerge at short notice: the initiative belongs to the entrepreneur and the industrial developer. Thus, an opportunity soon becomes in a very short time a "development realized" , for which the necessary local building permits are obtained. Usually, local administrations are unable to anticipate the industrial developer's intentions. As a result projects are being approved at the risk of legal wranglings between developer and local authority, a situation municipal councils dislike and cannot afford, financially, or politically. The largest schemes are therefore approved quite quickly.

The Lake region has recently experienced a number of above described development projects, all developed with a minimum of public debate or consultation, in which their overall impacting as well as long-term viability would have been scrutinized. A stocktaking of the study area would reveal some ten substantial projects undertaken and/or presently underway, usually only occasionally producing major debates as to their overall viability, their overall impacting on the surroundings and their "fit" with existing settlement, it be residential year-round or vacation home occupance. They are all located in localities that already have considerable pressure and the new projects will therefore add to the existing pressures on the sane set of recreational resource supply. At least 1000 condo units are being constructed and their impact upon lake and mountain resources will be considerable, both indirectly and in a very direct way. This means that access points, access roads and the various specific tourist facilities can expect larger crowds both summer and winter. The urban settlements toward which the demand will be directed will face substantial increases in traffic circulation and parking requirements, the boat launching sites around the lake will become more crowded with longer line ups and more informal parking, the risk for local beach areas to become polluted and closed during peak season will greatly increase and we can expect an expansion of the areas around the lake shoreline already experiencing unacceptable pollution levels. The strong volontary efforts to maintain acceptable quality levels for the lake will face further challenges in the future. - It is quite clear that the open, spontaneous approach to tourist - recreation project development will have very serious consequences for the TP which everyone seems so eager to exploit for recreational purposes, as well as for industrial profits.

\section{Opportunities lost - and efforts of revitalization}

The study region, which has been demonstrated above, experienced a touristic development with no particular constraints applied for well over one hundred years. For the most part of this long development span no major complications have arisen; only in the past 30 years, approximately, have strains and more serious implications as a result of tourist-derived development become clearly more visible. Since the mid 1960's many new features have started to have a more serious impacting upon the lake itself as well as upon a fairly wide surrounding area. The most prominent way in which the impacting has made itself felt may very well be the consequences of the effective closing of shoreline access through cottage development, a phase, which in turn left the increasing metropolitan an urban crowds with only a few access points to one of the best, and largest lake regions within easy access. Thus, demand, which previously could be diffused over a fairly long contact zone with the lake causing little if any concentrations, now instead faced a situation, where only a handful of locations had to accomodate the weekend visitors, who also brought recrea- tional equipement - boats, sailboards, etc. in large quantities and subsequently required not only access to the lake, but also space on land for parking and basic visitor service facilities. The pressure was on. Further, with the urban demand growing for non-urban vacation properties to very high levels, the opportunity for the "industrial developer" emerged. The result: a sudden boom in both cottage colony development schemes (as can be seen at Cherry River Village) and substantial condo schemes, both in urban areas (Magog) and adjacent to major tourist centres (ski hills - Mt. Orford and Owl's Head) as well as in any other location, where land could be obtained in combination with some access path down to the lakeshore (the L'Anse scheme on the Georgeville Road). Thus, a dangerous situation has arisen and the question should be asked as to why so little foresight has been applied to the situation. In hindsight it is of course easy to explain where it started to go wrong.

The most obvious explanation to the present situation lies in the fact that land resource management beyond privately owned property compound is an unfamiliar concept to Canadian society in general. The concept is vigorously applied to areas under singular management control - national and provincial parks, or for that matter corporately owned land resources, they be in urban or non-urban settings. However, as far as the exploitation of recreation-touristic resource lands go, one has maintained an outdated attitude, which extols the virtuous rights of the property owner to realize his resource in an open market economic system. Thus, a strong, buy and demand for recreational properties in a peripheral, less developed area places all the strong cards in the hand of the developer and financier.

A second complicating factor can be associated with "municipal geography". The lake region is the home of eight shoreline municipalities with another 15 making up the $M R C$ region; the variation among the eight is considerable, with Magog - a major industrial city turned touristic at one extreme and Potton at the other - both featuring substantial development schemes exploiting major tourist attractions within their respective boundaries. Local aims and objectives are indeed very different, which makes for different perceptions as to benefits of large industrial-touristic projects.

A third factor rests with the provincial authorities concerned with tourism on one hand and other responsibilities, such as environment, on the other. Here, ministerial responsibilities may run at cross purposes to the detriment of sound land resource management planning.

A fourth factor is of course the realization that TP:s in general know no man-made boundaries or jurisdictions. Thus, it is diffiicult to consolidate both mind and matter so that one can recognize the need for a holistic approach in development matters. A final factor can be found in the trends underlying the market forces that fuel the develop- 
ment process as such. There is ample evidence that it may be difficult to enforce constraining or blocking policies, even when these are very much justified, when demand has become truly widespread and popular. There is a reluctance in political administrations to say no to popular demand. To say no to recreational aspirations is even worse, because it infringes upon the individuals' private and very personal preferences.

In spite of the points raised above a number of planning efforts have over the decades been undertaken in the area. Evidently, with the establishment of the Orford Provincial Park some serious effort went into a development plan for that unit, sometime in the $1940^{\prime} \mathrm{s}$ and 1950 's, and today as well. However, a more holistic regional approach was presented in the early 1970's with the SORES Lake Area Development Plan. This study included a number of important features, all very appropriate for a tourist development plan: land use, public access, road system, major centres for visitor services camping, landings, marinas, altogether a comprehensive document. However, the study was flawed on two major points: first, it had failed to engage in participatory planning and ran therefore into strong criticism from residents in the area, both year-round and summer residents. Second, there was little analysis of the carrying capacity levels for the environment, in terms of various forms of recrational usage. It was basically a demand-derived study with inadequate concern for the survival of the recreational supply and its quality. Indeed it could have meant the destruction of the tourist resource by the tourists.

In the early 1980's a new effort was launched with the objective of formulating a development plan utilizing the newly formed MRC planning framework. In general the MRC plans are results of development plans prepared by the individual municipalities that make up the MRC grouping. Sometimes the MRC plan is good and indeed takes a serious approach - and a long term perspective to existing problems. Often, however, the municipal inputs simply reflect the rather egotistical aspirations of the municipality in question. The MRC lake area plan document recognizes many of the problems one presently is facing, but evidently there has been gaps in the implementation of the plan, witness the over 1000 new condo units that translate easily into 500 extra boats with additional land-based services to go with this, and one can visualize major consequences, on land as well as in the lake. Again, the plan fails to come to grips with "strategy", long term strategy, of and to what limits the resources can be exploited and what timeframe to set for future developments.

\section{An international tourist attraction complicates matters}

If the situation on the Canadian side of the lake is confusing and very much open, one must also recognize that the attractions to be developed are only partly under CanadianQuebec jurisdiction. The lake resource is in- ternational with a substantial portion located in Vermont. This calls for an approach not only in terms of such matters as lake water level management to be jointly administered, but also matters pertaining to the development of the TP in itself. Newport at the southern tip of the lake is potentially as strong a growth point for tourist services as is Magog. The nearby Jay Peak is a second, popular destination for Americans and Canadians. And the US shoreline has a strong appeal more broadly in Vermont, where, with the exception for Lake Champlain and a few minor lakes, lakes are not that numerous. Thus demand pressures and condo developments are juxtaposing with results quite similar to what can be observed further up the lake. Consequently, there is a strong need for establishing a comprehensive lake area strategy and a joint tourist resource management committee to go with it. Little of this is presently coming and the results of these deficiencies will be sufferings in the near future. There are positive precedences for joint environmental management structures along the borderline US/Canada. In the west the Waterton Lakes National Park straddles the 49th parallel and the two national parks administrations have agreed upon compatible management plans. Thus, here then, in the Lake Memphremagog region there is a fundamental need to operate joint development strategies, or conservation policies, if one wishes to maintain the quality of the tourist resources presently being consumed at a frightful tempo.

\section{A dimming future?}

Butler's development curve for tourist destinations have both a positive and a more serious part. The positive phase is the exciting discovery of new undeveloped destination milieus, first by the first-generation of visitors - the explorers, the touristic pathfinders, that invariably open up new destinations; the less positive part of Butler's evolution cycle suggests a consolidation and stagnation with, sometimes, the possibilities for a rejuvenation, by which the area takes on a new vigorous growth phase. Our study region has seen the early part of Butler's model diagram and has, in my opinion, also come close to the "levelling off" in the growth cycle. Even if there now seems to exist the potential for a renewed phase of development, this new phase carries with it serious consequences for the destination area, simply because it is the same grouping of attractions, that pulls in the new clientele - the lake and park in summer and the two ski centres in winter. Thus, the pressures of usage will be even further accentuated with little recourse when the "deed has been done". The responsibility for the situation rests obviously with the local and regional public authorities, as well as with the province that has aided in the present acceleration of the development tempo. However, the responsibility rests, likewise, with the industrial developer, who has yet to show restraint in his development interest, and by that restraint reducing the dangers that otherwise might imperil the lake area - Lake Mem- would like to see survive the future in a healthy state as a tourist destination. $f$

Notes explicatives

(1) The notion of interdependent travel functions, that together constitute the tourist travel phenomenon was originally developed by the author and first presented in his articte The development of the Tourist Travel Systems ljanvier/mars, 1973, The Tourist Review, Berne, La Suissel- Since, the con. cept has been elatiorated by numerous authors on different geographic scale levels; see for instance D. Pearce, Towand a Goography of Towism [1979, Annals of Tourism Research, 6131, 245-72) and S. Brit. ton, The Political Economy of Tourism (1982, An. nals of Tourism Research, 9(3), 331-58).

(2) Classifications of tourist destinations have figured widely in the literature, but they have basically been associated with seasonality and location - winter tourist resorts, spas, seaside resorts -, frequently published in Atlases and for business purposes. Here, the classification is based on artraction compostion, i.e. the dominance of one, or more components; that make up a destination environment. The idea is derived from Clawson, Held, Stoddard's identification of destination types (recreation areas), first published in Land for the Future $(1960)$ and later, in $\mathrm{M}$. Clawson's Economics of Outdoor Recreation. where reference is made to user-oriented 'inter. mediafe and resource-oriented destination areas, their resource attributes add recreational utility. The classification presented here has been modified to accomodate better the non-landscape components that often are dominant features in the make-up of destination areas.

(3) The concept of operational travel range for recrestional-touristic purposes was originally applied at two distinct geographic scale levels. Freda Raiotte analysed the recreational hinterland for the metropoli. tan area in her Ph.D. dissertation Quebec City and its recreational hintevland (McGill University, 1973). In $1975 \mathrm{~J}$. M. Miossec applied the same concept on a wider, continental-global level in his identification of Tourist Space - L'Espace Touristique - in his study Eléments pour une théorie de l'espace touristíque. in Les Cahiers du Tourisme (1976) - Aix-en-Provence. In our discussion, the two are combined as the study area is more appropriately situated in a recreationaf hinreflend demand sphere rather than in an interna. tional context. Note however, that the diagram (figy. 1) features, for more distants destinations, an in. creasing involvoment of additional travel-generating areas apart from the original T,G.A.

14) Regional recreational touristic landscape resources potential date have been gleaned from the map series Land Capability for Recreation, published by ARDA in its Canada Land Inventory program COtta. wo, $1969-71$

(5) The Cvele of Evolution of towist destinations was. a concept developed by R. Butler in 1980 . For details, read his article in the Canadian Geographer, No. 1. Spring 1980.

(6) Shoreline occupancy information can most conveniently be collected from either airphoto coverage or large scale topograhic map inventories. For our purposes the longest data series can be found in the cartographic map series; here, the 1916-1978 editions of the series was used at a scale of 1:63,500 and 1:50,000.

(7) Regional development plans, both old and more re: cent (MRC/MCl proposals) are available at the Township of Magog Office for consultation. The figure on the number of condo units presently under construction land/or recently finished) was provided through the Township Office, the same figure was also quoted in the Memphremagog Conservation Incorporatod News Bulletin [Vol. I, Winter 1988]. For details, consult the Township Office.

(8) A most comprehensive regional analysis of the environmental situation and the contemporary land use situation for the Lake Memphremagog drainage basin was prepared in 1982 by the Memphremagog Conservation Inc, organization by DE-Dimension Environnement Ltée, with a most detailed accounting of the situation for the municipalities that make up the study area, and with recommandations as to how shoreline sitting of cottages, etc. should be done in order to minimize impacting. This document served, partly as a base for the MRC development plan. 